\title{
Characteristics and Abilities of Teachers of English at Auchi Polytechnic, Auchi, Nigeria Vis-À-Vis Communicative Language Teaching (CLT)
}

\author{
Femi U. Balogun ${ }^{1 *}$, Joseph O. Ikupa ${ }^{2}$, Olusegun O. Aramide ${ }^{3}$ \\ ${ }^{I}$ Department of Languages, School of General Studies, Auchi Polytechnic, Auchi, Edo State, Nigeria \\ ${ }^{2}$ School of General Studies, Delta State Polytechnic, Oghara, Delta State, Nigeria \\ ${ }^{3}$ National Teachers' Institute (NTI), Igarra, Edo State, Nigeria
}

*Corresponding Author: Femi U. Balogun, Department of Languages, School of General Studies, Auchi Polytechnic, Auchi, Edo State, Nigeria

\begin{abstract}
It is often said that no one can give what he does not have. Can English Language teachers without a sound background in English for Specific Purposes (ESP) teach ESP effectively in Nigerian Polytechnics? This research, using teachers of English in Auchi Polytechnic as subjects, was carried out to determine the characteristics and abilities of teachers of English in Nigerian Polytechnics. The data were sourced primarily using a questionnaire. A 30-point questionnaire was used to elicit responses from the 18 teachers in the Languages Department of Auchi Polytechnic. Frequencies and percentages were used to answer the research question while chi-square statistics was used to test the hypothesis at 0.05 level of significance. The analyses showed that there is a significant relationship between the knowledge of ESP and characteristics and abilities of teachers of English. The study recommends that teachers of English in Polytechnics should be encouraged to acquire higher qualifications in ESP, ESL or Applied Linguistics that can make them better teachers of ESP.
\end{abstract}

Keywords: Abilities, Characteristics, ESP, Needs Analysis, Communicative Language Teaching (CLT)

\section{INTRODUCTION}

In Auchi Polytechnic, as indeed all other institutions of higher learning in Nigeria, English is the medium of instruction, since the language is a lingua franca and the official language of the country. Right from the primary up to the tertiary level, English is always taught and learnt. A variety of factors usually determine the success or otherwise of the teaching/learning as Cohen and Dornyei (2002:170) explain:

Success in learning a foreign or second language (L2) depends on a variety of factors such as the duration and intensity of the language course, the characteristics and abilities of the teacher, the appropriateness of the teaching methodology, the quality of the text book, the size and composition of the learner group, the amount of natural L2 practice opportunities, and last but not least the characteristics of the learner group (Emphasis mine).

It is common knowledge in Nigeria that learners of English at the primary and secondary school levels are hardly taught by specialists who studied the language scientifically. This had led Awobuluiyi (2010:34) to note that "students of linguistics are by their specialized training much better placed than most other categories of students to teach English as it really should be taught in the nation's schools." Whereas anyone can, and does, teach English at the primary and secondary levels to learners in the country (although this is inappropriate), the language is not taught by just any person at the tertiary level. It is taught by those who must have some or all ot the following qualifications: B.A. (English); M.A. (Applied Linguistics); M.A. (ESL); M.A. (Lit); M.A. (English); Ph.D (English);, etc. This is because, at the tertiary level, learners have become advanced and so require persons with appropriate knowledge and experience to teach them, using a variety of methods and approaches.

A number of approaches and methods have always been available for language teachers to explore and exploit since the history of language teaching began. Within the last quarter of the century, as 
noted by Savignon (2001:13), Communicative Language Teaching (CLT) has been put forth around the world as the 'new' or 'innovative' way to teach English as a second or foreign language. Teaching materials, course description and curriculum guidelines proclaim a goal of "communicative competence', an approach of the functionalists." This is in contrast to the grammatical competence which the approach of the formalists emphasized.

Communicative Language Teaching (CLT) is an FL/F2 teaching approach which makes use of reallife situations that necessitate or compel communication. The teacher sets up a situation that students are likely to encounter in real life, thereby compelling them to communicate not only in class but when they are confronted out there with such real-life situations.

$>$ It leaves students in suspense as to the outcome of a class exercise which will often vary according to their reactions and responses.

$>$ The real-life situations are changed from day to day.

$>$ Students' motivation to learn comes from their desire to communicate in meaningful ways about meaningful topics and real-life contexts in the FL (Target Language) Berns (1984).

Littlewood (1981), Yalden (1983), White (1988), and Sheldon (1988) in the last decades of the last century, had all commented on communicative language teaching. Ihebuzor (1993:20) summarized their views and comments as follows:

- CLT is learner-centered, i.e. the learner's goal and aspirations are central in objective setting, content selection, and choice of methodology.

- Sequence and grading of elements are based largely on these learner needs and on sociolinguistic considerations.

- The emphasis in teaching is on the function of language and language elements are selected and justified to the extent to which they meet the needs of learners in the areas of function, notions and situations.

- More emphasis is put, in the initial phase of teaching, on functional adequacy and appropriacy and less and less on grammatical accuracy.

- Sociolinguistic concerns about authentic language usage outweigh former emphasis in the GBM with grammar book-type of language. Materials for CLT simulate as closely as possible real-life communicative situations.

- The emphasis on sociolinguistic appropriacy and adequacy presupposes teachers who are not only linguistically competent, but who are also communicatively competent, i.e. teachers who have a functional knowledge and command of the code (Emphasis mine).

- The methodology leans heavily on active learner participation. This, in turn, demands the use of methodologies and materials that are task-based, cognitive and challenging. Such materials and methodologies would include information gap exercises, dehydrated utterances, role play, simulations, peer and group work, dramatization, etc. Language content is internalized in the course of such exercises.

- The emphasis on active participation demands small class sizes. It precludes large classes.

- The emphasis on active participation calls for a classroom management strategy that is liberal, tolerates movement, controlled role set and definitions. It enlarges the teacher's role to that of facilitator, helper, consultant and at times, dramatist.

- The simulation of real-life situations usually requires the use of instructional materials - video tapes, slides, etc.

- CLT calls for an integrative assessment procedure that forces learners to display actual communicative ability in life-like tasks and not knowledge of discrete linguistic rules. Scoring in such tests would focus on communicative worth and adequacy and is bound to be less discrete.

Nattinger (1993 p.599) had also commented enthusiastically about the communicative language teaching method that it has "the possibility of being less limited than the notional ones, less 
ethnocentric than many humanistic methods, and less psycho-linguistically objectionable than audiolingual ones." CLT is thus, a total package made up of aims, objectives, assumptions, contents, methodology, and materials. It still holds sway, even in the second decade of this century.

While some people may believe that the cause of success or failure in language learning is the method used, others will content that the teachers is the sole focal element in the language teaching operation, for after all, methods are only as good as their teachers. Although one sees both as crucial, this paper however, focuses on and examines the characteristics and abilities of teachers of English in Nigerian Polytechnics, using Auchi Polytechnic as an example, taking into consideration the communicative competence approach of the modern times.

\subsection{Statement of the Problem}

Nigerian Polytechnic students are advanced learners of English. Balogun (1997:4) argued that "because of the technical and technological bent of Polytechnics in Nigeria, the students quite appropriately qualify as ESP learners whose needs cannot be 'global', but must be specified from the outset." He went further to argue that by the same token, English programmes in Polytechnics should qualify as ESP courses where the syllabus and materials should be determined in all essentials by prior analysis of the communication needs of the learners, rather than by "non-teacher-centered criteria such as the teacher's or institution's predetermined preferences for General English or for treating English as part of a general education" (Munby, 1997:2)

If English programmes in Polytechnics in Nigeria should be ESP, then they should not be handled by just any person. Johns and Price-Machado (2001:46) emphasized this point when they asserted:

A central issue to be considered is the nature of the teachers who will be involved in an ESP programme. What content, skills, and literacies will they be expected to teach? How much teacher training have they completed? Are they linguistically sophisticated? ... inexperienced or "traditional" teachers cannot work within an ESP content, for example. (Emphasis mine).

The above happens to be the condition of language teachers in Polytechnics in Nigeria, where a majority of them do not have departments of languages, but language units in departments of General Studies. At Auchi Polytechnic, however, there exists a department of languages which comprises two graduates in French, nineteen graduates in English and none in any Nigerian language.

The issue which then arises for this study is: what are the characteristics and abilities of these English teachers in Auchi Polytechnic? Are they linguistically competent and professionally qualified?

\subsection{Purpose of the Study}

The purpose of the study is to find out the characteristics and abilities of teachers of English in Auchi Polytechnic i.e. whether they are sufficiently knowledgeable about ESP and professionally qualified to teach ESP to the advanced learners that make up polytechnic students - engineers, accountants, administrators, surveyors, scientists, technologists, etc.

\subsection{Research Questions}

The following research question has been formulated based on the above research problem:

To what extent are the characteristics and abilities of teachers of English in Auchi Polytechnic adequate for handling ESP courses, taking into consideration the teachers' qualifications, experience and background?

\subsection{Hypothesis}

Ho: There is no significant relationship between the characteristics and abilities of teachers of English in Auchi Polytechnic and ESP Courses.

\section{REVIEW OF RELATED LITERATURE}

\subsection{What is ESP?}

English for Specific Purposes (ESP), an out-growth of the age-long English Language Teaching (ELT) is a movement based on the proposition that "all language teaching should be tailored to the specific learning and language-use needs of identified groups or students" (Johns and Price-Machado, 
2001:43). Dudley-Evans and St. John (2006:1) reveal that "since the 1960s ESP has become a vital and innovative activity within the teaching of English as a Foreign and Second language movement (TEFL/TESL)."

For its definition, Hutchinson and Waters (1987), Strevens (1988) and Robinson (1991) have variously been cited. Not quite satisfied with the various definitions, Dudley-Evans and St. John (2006:4-5) proceeded to state: Our definition is:

\subsubsection{Absolute characteristics}

- ESP is designed to meet specific needs of the learners

- ESP makes use of the underlying methodology and activities of the discipline it serves;

- ESP is centered on the language (grammar, lexis, register), skills, discourse and genres appropriate to these activities.

\subsubsection{Variable Characteristics}

- ESP may be related to or designed for specific disciplines;

- ESP may use, in specific teaching situations, a different methodology from that of general English;

- ESP is likely to be designed for adult learners, either at a tertiary level institution or in a professional work situation. It could, however, be used for learners at secondary school level;

- ESP is generally designed for intermediate or advanced students.

- Most ESP courses assume basic knowledge of the language system, but it can be used with beginners.

It must be pointed out here that neither in this definition nor in others before it, is mention made of the teacher. This is because it is assumed (quite incorrectly in the case of Nigeria) that the ESP teacher is professionally and linguistically competent.

Even when Yildiz (2004) also explained that ESP is known as a learner-centered approach to teaching English as a foreign or second language, which meets the needs of mostly adult learners who need to learn a foreign language for use in the specific fields such as science, technology, medicine, leisure, and academic learning, he did not make mention of the teacher.

A crystallization of the communicative approach and communicative language teaching methods, ESP has stages and is divided into three categories as follows: English for Academic Purposes (EAP); English for Occupational or Vocational Purpose (EOP) or (EVP); and English for Professional Purposes (EPP). Dudley-Evans and St. John (2006:12) explain that 'the key stages in ESP are: needs analysis, course (and syllabus) design, materials selection (and production), teaching and learning, and evaluation."

The following presupposes that the characteristics and abilities of the teacher are guaranteed. It has earlier on been pointed out by Hutchinson and Waters (1987:53-54) that:

If we had to state in practical terms the irreducible minimum of an ESP to course design, it would be needs analysis, since it is the awareness of a target situation - a definable need to communicate in English - that distinguishes the ESP learner from the learner of General English.

Thus, needs analysis is very important in ESP operations. Its purpose, notes Gardner and Winslow (1983:7) "is to produce information which when acted upon, makes course better adapted to students' needs. Needs Analysis (NA) is to the functionalists what Contrastive Analysis (CA) and Error Analysis (EA) are to the formalists.

Earlier in the history of NA, the dominant focus was occupational (English for Occupational Purposes), but this later changed to English for Academic Purposes (EAP). Since the middle of the last century to the present day, there have been several approaches to NA. Some of them include James (1974), Chambers (1980), Robinson (1981), Bell (1981), Widdowson (1981), McDonough 
(1984), Kennedy and Botitho (1984), Tickoo (1987), Hutchinson and Waters (1987), Swale (1988), Dudley-Evans and St. John (2006). Munby (1978) is credited as the first to come up with the Communicative Needs Processor (CNP) which provides a guideline on how to carry out NA. All others have been either a modification or an adaptation of the Munbyan model.

\subsection{How ESP is different from General English}

In General English, as a general rule, all four language skills - listening, reading, speaking and writing are stressed equally, but in ESP, it is a needs analysis (NA) that determines which language skills are most needed by the students, and the syllabus is designed accordingly (Fiorito, 2005). ESP learners like Polytechnic students are usually adults who already have some acquaintance with English and are therefore learning the language in order to communicate a set of professional skills and to perform job-related functions. Fiorito (2005) explains further that ESP combines subject-matter and English language teaching spirit; such a combination enables students to apply what they learn in their English classes to their main field of study.

The most important difference between ESP and General English (also known as English as a Second Language (ESL), lies in the learners and their purpose of learning English. For example, an ESP programme might emphasize the development of reading skills in learners who are preparing for graduate work in public administration or it might promote the development of spoken skills in learners who are studying English in order to become tourist guides or bar attendants in international five-star hotels. In Nigerian Polytechnics, English for academic purposes and for occupational purposes ought to be the focus at the National Diploma and Higher National Diploma levels. The current newly-revised syllabus tends to be along the line. While the "communication in English" content of the syllabus is not targeted at any particular discipline, "Business Communication" and "Technical English" courses are targeted at Business and Science and Technology students respectively (Balogun, 2017).

In Nigeria, in the 1980s, the Communication Skills Project (COMSKIP) was launched at the University of Ibadan. It led to the production of Needs Analysis of Communication Skills in Nigerian Universities (1990). The document contains needs analysis questionnaires that were used to investigate the writing, speaking, reading and listening skills of some selected university students in Nigeria. The document has been used as a guide in drawing up the questionnaire for this research even though this is not a needs analysis, but a research in ESP.

Empirical studies on ESP and its teachers abound. One of such is Maleki (2008).

Maleki (2008) conducted a research in Iran to find out who is better suited to teach ESP. He found out that it is English graduates with a background in ESP or Applied Linguistics in Nigeria, the literature search did not reveal any.

The literature review, thus, reveals a gap which this study tries to inquire into and that is characteristics and abilities of the teacher in ESP operations: (In needs analysis (NA) this is not always emphasized; it is erroneously assumed to be adequate, especially in Nigeria, where a majority of English teachers in Polytechnics specialize in Literature rather than ESP, ESL or Applied Linguistic.

\subsection{Significance of the Study}

The significance of the study lies in the fact that it will assist in preparing teachers of English in Polytechnics in Nigeria to be better teachers who will impart the appropriate knowledge to the learners. This will consequently lead to the production of proficient products that can perform well in the target situation and so reduce the complaints of employers about the incompetence of Polytechnic graduates.

\subsection{Research Methodology}

Academic staff of the Department of Languages in the School of General Studies were administered a questionnaire titled: "Communicative Language Teaching and the Polytechnic Teachers of English" (see Appendix). It contains 30 items which require responses. They covered various aspects of ESP and the teachers' qualification and experience. 18 questionnaires returned were academic staff 
in the English Language Unit which confirms the scope of the research studies. The analysis is based on the 18 respondents. The data were presented in a tabular form and analysis was done electronically with the aid of computer package (Excel) for percentage analysis and chart. Statistical technique such as chi-square was adopted as inferential tool to test for the research hypothesis at 0.05 level of significance. The test of hypothesis was conducted by the use of statistical software - SPSS (Statistical Package for the Social Sciences) version 17.0. The data were sourced primarily through the method of questionnaire. The questionnaire comprised thirty items which seek to provide answers to the research question. It was validated by a language teacher who raised the number of items from 26 to 30 .

\section{DAta Presentation, ANAlysis ANd Discussion}

\subsection{Research Question}

To what extent are the characteristics and abilities of teachers of English in Auchi Polytechnic adequate for handling ESP courses, taking into consideration the teachers' qualifications, experience and background?

Items 16, 18, 19, 20, 21 and 27 of the questionnaire provide answers to the above research questions.

Tables I, II, III and IV represent an overview of the research question along with its questions and questionnaire items.

Table I. Characteristics/Ability of Teachers in ESP * Response

\begin{tabular}{|l|c|c|c|}
\hline \multirow{2}{*}{ Item 16, 18, 19, and 20 characteristics/ability of Teachers } & \multicolumn{2}{c|}{ Response } & \multirow{2}{*}{ Total } \\
\cline { 2 - 3 } & Yes & No & \\
\hline Conversance Observed with ESP & 6 & 3 & 9 \\
Expected Approaches & 5.0 & 4.0 & 9.0 \\
$\%$ within Response and Methodology & $60.0 \%$ & $37.5 \%$ & $50.0 \%$ \\
\hline Professional Observed & 2 & 3 & 5 \\
Qualification Expected & 2.8 & 2.2 & 5.0 \\
$\%$ within Response & $20.0 \%$ & $37.5 \%$ & $27.8 \%$ \\
\hline Background Observed & 2 & 2 & 4 \\
Expected & 2.2 & 1.8 & 4.0 \\
$\%$ within Response & $20.0 \%$ & 25.05 & $22.2 \%$ \\
\hline Total Observed & 10 & 8 & 18 \\
\multicolumn{1}{|c|}{ Expected } & 10.0 & 8.0 & 18.0 \\
\hline \% within Response & $100.0 \%$ & $100.0 \%$ & $100.5 \%$ \\
\hline
\end{tabular}

Source: Field Survey, 2017

Table II. Chi Square Tests

\begin{tabular}{|l|c|c|c|}
\hline & Value & Df & Asymp. Sign. (2 sided) \\
\hline Pearson Chi-Square & $.0990^{\mathrm{a}}$ & 2 & .610 \\
\hline Likelihood Ratio & .998 & 2 & .607 \\
\hline Linear-by-Linear Association & .492 & 1 & .483 \\
\hline No. of Valid Cases & 18 & & \\
\hline
\end{tabular}

a. 5 cells $(83.3 \%)$ have expected count less than 5 . The minimum expected is 1.78 .

Table III. Table for item 19: Conversance with ESP Approaches and Methods

\begin{tabular}{|l|c|c|}
\hline \multicolumn{1}{|c|}{ Conversance with ESP application and method } & Frequency & Percentage \\
\hline Yes & 7 & $38.89 \%$ \\
\hline No & 11 & $61.11 \%$ \\
\hline Total & 18 & $100.00 \%$ \\
\hline
\end{tabular}

Source: Field Survey, 2017

On the conversance with ESP approaches and methods, the frequency response analysis revealed that out of 18 respondents 11 said NO to being conversant with ESP approaches and methods making $61 \%$ while 39\% said YES. Generally, there is disagreement on conversance with ESP approaches and methods among the academic staff of the Polytechnic. Not many of the teachers are conversant with 
ESP approaches and methodology. Those conversant with ESP approaches and methods are those who recently (in 2010 and 2014) returned from Malaysia, where they acquired higher qualifications in Applied Linguistics.

Table IV. Table for items 21: Response on Conversance with NEEDS Analysis

\begin{tabular}{|l|c|c|}
\hline \multicolumn{1}{|c|}{ Response } & Freq. & Percent \\
\hline YES & 6 & $33 \%$ \\
\hline NO & 12 & $67 \%$ \\
\hline Total & 18 & $100 \%$ \\
\hline
\end{tabular}

Source: Field Survey, 2017

Based on the conversance with the NEEDS analysis response, the frequency response analysis showed that out of 18 respondents 12 said NO to being conversant with Needs Analysis making 67\% while $6(33 \%)$ said YES. NA is the first stage in any ESP operation and yet many teachers here are not conversant with it. This proves the assumption that ESP teachers in Auchi Polytechnic are linguistically competent, wrong.

\subsection{Test of Hypothesis (Ho)}

Ho: There is no significant relationship between the characteristics and abilities of teachers of English in Auchi Polytechnic and ESP courses.

$$
\begin{aligned}
& \text { Ô }\left(0_{1}-\mathrm{e}_{1}\right)^{2} \\
& \mathrm{C}^{2} \mathrm{cal}=\frac{\mathrm{I}=1}{\mathrm{e}_{1}} \\
& \mathrm{C}^{2} \mathrm{cal}=0.99
\end{aligned}
$$

Test Statistics (P value)

$\mathrm{C}^{2} \mathrm{tab}=\mathrm{c}^{2}(\mathrm{r}-1)(\mathrm{e}-1) \mathrm{a}$

$\mathrm{C}^{2} \mathrm{tab}=\mathrm{c}^{2}(3-1)(2-1) 0.05$

$\mathrm{C}^{2} \mathrm{tab}=\mathrm{c}^{2}(2)(1) 0.05$

$\mathrm{C}_{2}^{2} 0.05=0.610$

\subsection{Decision Rule}

If $\mathrm{c}^{2} \mathrm{cal}<\mathrm{c}^{2}$ tab, we accept Ho

If $\mathrm{c}^{2} \mathrm{cal}>\mathrm{c}^{2}$ tab, we do not accept Ho

\subsection{Findings and Discussion}

Since $c^{2}$ cal (0.99) > $c^{2}$ tab (0.610), we do not accept Ho. Based on the analysis we accept $\mathbf{H}_{\mathbf{i}}$ and conclude that there is significant relationship between the characteristics and abilities of teachers of English in Auchi Polytechnic and ESP courses. This is true because of the percentage analysis of YES response on conversance with ESP approaches and methods making 60\%. This implies that teachers are conversant with ESP approaches and methods but have no professional qualification and background or experience to teach ESP in the Polytechnic. This is further explained by the higher qualifications possessed by the teachers which are mainly in Literature and English rather than Applied Linguistics and ESL. This could account for the rife complaints by employers in Nigeria against the inability of Polytechnic graduates to perform proficiently in the target situation (Balogun, 2017).

\section{CONClusion}

A majority of teachers of English in Nigerian Polytechnics do not have ESP background though they have second degrees. It is clear, therefore, from the hypothesis and the research question that without a background in ESP, one might not be able to teach ESP courses effectively. This confirms the observation of Johns and Price-Machado (2001) and supports the admonition of Awobuluiyi (2010). Besides, in a study to find out who should teach ESP, Maleki (2008) found out that English graduates 
with qualifications in ESP are more favoured to teach ESP/EFL because they handle it better. This study further lends credence to the findings of Maleki (2008) concerning ESP teaching in Iran.

\section{RECOMMENDATIONS}

The following recommendations are made:

- Efforts should be made to send teachers for professional qualification in ESP.

- There is need for improvement in the NBTE syllabus to make it ESP-compliant to guarantee communicative competence among others.

- The British Council should be approached for assistance in training English Teachers in Polytechnics in Nigeria, on ESP methodology and approaches, from time to time.

- Seminars, conferences and workshops should be organized regularly by professionals on Needs Analysis in ESP operations.

- Some universities should be designated as Centres of Applied Linguistics Research where Polytechnic teachers of English can be sent for more training.

\section{SUGGESTIONS FOR FURTHER RESEARCH}

In keeping with the Communicative Language Teaching (CLT) of the present time, it is recommended that the background of English teachers in other Polytechnics in the country be investigated in this manner. This will help to reposition the teaching of English courses in Polytechnics which are ESP based.

\section{REFERENCES}

[1] Awobuluiyi, O. (2010). "Linguistics and Nation Building". The Prof. Emeritus Ayo Bamgbose Personality Lecture. Ibadan: DB Mantoy Books/LINSA

[2] Balogun, F.U. (1997). Needs Analysis: The Case of Secretarial Students at Auchi Polytechnic, Auchi, Edo State. Unpublished M.A. Dissertation, UNN

[3] Balogun, F.U. (2017). A Needs Analysis of the Writing Skills of HND Business Studies students at Auchi Polytechnic, Edo State. International Journal of English and Literature, Vol. No. 6 ISSN 2141-2626

[4] Bell, R.T. (1981). An Introduction to Applied Linguistics: Approaches and Methods in Language Teaching. London: Batsford

[5] Berns, M.S. (1984). Functional approaches to language and language teaching: Another look. In Sauvignon, S \& M.S. Berns (eds) Initiatives in communicative language teaching: A book of reading. Chicago: Mass: Addison-Wesley Pub. Co.

[6] Chambers, F. (1980).. "A Re-evaluation in ESP" $\quad$ ESP Journal 1 (11) 25 - 33.

[7] Cohen, A.D. and Dornyei, Z. (2002). "Focus on the Language Learner: Motivation, Styles and Strategies". An Introduction to Applied Linguistics, edited by N. Schmitt. London: Arnold

[8] Dudley-Evans, T. and St. John, M.J. (2006). Developments in English for Specific Purposes: A Multidisciplinary Approach. Cambridge: Cambridge University Press

[9] Fiorito, L. (2005). Teaching English for Specific Purposes (ESP). How is ESP different from ESL, also known as general English? Teaching English for Specific Purposes (ESP). Teacher Article U... Available at file:///c:Documents \%20 and settings/USER/my\%20Documents/...Retrieved 7/15/2011

[10] Gardner, P.H. and J.D. Winslow (1983). Present and Proposed Methods of Determining the needs of students in Public Sector identifying language needs. Pergamum Press

[11] Hutchinson, T. and Waters, A. (1987). English for Specific Purposes: A Learning-centered Approach. Cambridge University Press

[12] Ihebuzor, N. (1993). "Socio-pedagogic Constraints and Curriculum Innovation - Communicative Language Teaching in Nigeria as a Case Study". Education Today, Vol. 6, No. 4 (pp 20 -23).

[13] James, G. (ed) (1984). "The ESP Classroom: Methodology, Materials, Expectations. Exeter Linguistic Studies. 7, Exeter: University of Exeter

[14] Johns, A.M. and D. Price-Machado (2001). English for Specific Purposes (ESP) Tailoring "Courses to Students and to the Outside World." In Teaching English as a Second or Foreign Language ( $3^{\text {rd }}$ edition), edited by Mr. Celce-Murcia. Boston M.A.: Heinle \& Heinle

[15] Kennedy, C. and Bolitho, R. (1984). English for Specific Purposes. London: Macmillan 
[16] Littlewood, W. (1981). Communicative Language Teaching, Cambridge: Cambridge University Press.

[17] Mackey, W.F. (1965). Language Teaching Analysis. London: Longman

[18] Maleki, A. (2008)). "ESP Teaching: A Matter of Controversy". ESPWorld Issue No. 1 (17) Vol.7, Available at http://esp-world.info

[19] McDonough, J. (1985). ESP in Perspective: A Practical Guide. London: Collins ELT.

[20] Munby, J. (1978). Communicative Syllabus Design. Cambridge: Cambridge University Press

[21] Nattinger, J.R. (1993). Communicative Language Teaching: A New Metaphor 18(3)

[22] Robinson, P (1991). . ESP Today: A Practitioner's Guide. Hemel Hempstead: Prentice Hall Intn'l

[23] Savignon, S.J. (2001). “Communicative Language Teaching for the Twenty-First Century”. In M. CelceMurcia (ed) Teaching English as a Second or Foreign Languag e ( ${ }^{\text {rd }}$ ed.). Boston, M.A.: Heinle and Heinle

[24] Sheldon, L. (ed) (1988). ELT Textbooks and Materials: Problems in Evaluation and Development. Basingstoke: MacMillian and MEP.

[25] Strevens, P. (1988). "ESP after twenty years: A re-appraisal. In M. Tiekoo (ed). ESP: State of the Art. Singapore: SEAMEO Regional Language

[26] Swale, J.M. (1988). Episode in ESP: A Source and Reference Book on the Development of English for Science and Technology. New York: Prentice Hall

[27] Tickoo, M.L. (1987). "Episodes in ESP” RELC Journal 17(2).

[28] Ubahalewe, E. and Ntia, U.N. (eds) (1990). Needs Analysis of Communication Skills in Nigerian Universities. Ibadan: Comskpi Publication Series

[29] White, R.V. (1988). The ELT Curriculum, Design, Innovation and Management. Oxford: Basil Blackwell

[30] Widdowson, H.G. (1981). "English for Academic Purposes: Criteria for Course Design." In Selinker, L., Tarone, E. and Hanzeli, V. (eds). English for Academic and Technical Purposes. Rowley, Massachusetts: Newbury House.

[31] Yalden, J. (1963). The Communicative Syllabus: Evolution, Design and Implementation,. Pengamon Press

[32] Yildiz, S. (2004). "Teaching English for Specific Purposes". Available at http://www.indiana.edu/1630tesp/

\section{APPENDIX}

Department of Languages, School of General Studies,

Auchi Polytechnic,

Auchi.

Dear Respondents,

\section{Communicative Language Teaching and the Polytechnic Teachers of English}

This instrument/questionnaire is designed to find out how the teaching of English in Polytechnics can be improved and made more relevant in line with the spirit of communicative competence of the new millennium.

It would be highly appreciated if you answer the questions as simply and objectively as possible and return the instrument.

Thanks.

\section{Section A: Background Information}

1. Name of Institution:

2. Indicate Institution status; Federal [ ] State [ ] Private [ ]

3. Region: East [ ] North [ ] West [ ]

4. Is there an English Dept/Unit/Division in the Institution? Yes [ ] No [ ]

5. How many staff members make up the Dept/Unit/Division?

6. Do you consider t3he number adequate? Yes [ ] No [ ]

7. How many departments are in the entire Institution?

8. Do all the departments take English courses? Yes [ ] No [ ] 
9. At what level do they take English courses?

10. Would you regard the type of English taught there as Englsh for Specific Purposes (ESP)? Yes [ ] No [ ]

11. Would you regard the students as Elementary [ ] Intermediate [ ] or Advanced [ ] learners?

12. Do you notice any impact of English courses on the student's Receptive \& Productivity skills Yes [ ] No [ ].

13. Apart from tests, quizzes and examination, do you have any other defined channel for ge 3tting feedback on impact of English courses on students' communicative competence? Yes [ ] No [ ]

14. If any, specify:

15. Is there opportunity to channel the feedback for syllabus enrichment? Yes [ ] No [ ]

\section{Section B: Characteristics and Abilities}

16. What is your qualification? Please tick as appropriate.

B.A. [ ] M.A. (ESL) [ ] M.A. (Applied Lings) [ ] M.A. English [ ]

M.A. (Litt) [ ] Ph.D [ ] or any other, please specify:

17. At what level(s) do you teach English? ND [ ] HND [ ]

18. How long have you been teaching in the institution?

19. Are you conversant with English for Specific Purpose (ESP) Approach and Methodology? Yes [ ] No [ ]

20. While a student, were you exposed to ESP? or Do you have a background in ESP?

Yes [ ] No [ ]

21. Are you conversant with Needs Analysis (NA)? Yes [ ] No [ ]

22. Looking at the current NBTE syllabus, would you say it is based on any Needs Analysis (NA)? Yes [ ] No [ ]

23. Looking at the current NBTE syllabus, would you say it satisfies the requirements of English for Occupational Purposes (EOP) [ ] English for Academic Purposes (EAP) [ ] English for Business Purposes (EBP) [ ] or English for General Purposes (EGP) [ ] (Tick as applicable).

24. Does your department observe any criteria for allocating courses in English to lecturers? Yes [ ] No [ ]

25. Please, mention any two:.

26. Does the department operate an in-house mechanism for monitoring field performance of teachers in English? Yes [ ] No [ ]

27. Have you ever attended any workshop/seminar/conference on syllabus design?

Yes [ ] No [ ]

28. Has your opinion ever been sought on syllabus design? Yes [ ] No [ ]

29. Do you observe any inadequacies in the NBTE syllabus? Yes [ ] No [ ]

30. State such inadequacies briefly:

Citation: Femi U. Balogun, Joseph O. Ikupa, Olusegun O. Aramide. "Characteristics and Abilities of Teachers of English at Auchi Polytechnic, Auchi, Nigeria Vis-À-Vis Communicative Language Teaching $(C L T)^{\prime \prime}$ International Journal on Studies in English Language and Literature (IJSELL), vol 6, no. 4, 2018, pp. 16-25. doi:http://dx.doi.org/10.20431/2347-3134.0604002.

Copyright: () 2018 Authors. This is an open-access article distributed under the terms of the Creative Commons Attribution License, which permits unrestricted use, distribution, and reproduction in any medium, provided the original author and source are credited. 